\title{
Differential Representation of Landmark and Self-Motion Information along the CA1 Radial Axis: Self-Motion Generated Place Fields Shift toward Landmarks during Septal Inactivation
}

\author{
Mohammad Fattahi, ${ }^{1,2}$ @ Farnaz Sharif, ${ }^{1,2}$ Tristan Geiller, ${ }^{1}$ and $\mathbb{C S}^{-S e ́ b a s t i e n ~ R o y e r ~}{ }^{1,2}$ \\ ${ }^{1}$ Center for Functional Connectomics, Korea Institute of Science and Technology, Seoul 136-791, Republic of Korea and ${ }^{2}$ Department of Neuroscience, \\ Korea University of Science and Technology, Daejeon 305-350, Republic of Korea
}

Spatial location in the environment can be defined in relation to specific landmarks or in relation to the global context, and is estimated from both the sensing of landmarks and the inner sense of cumulated locomotion referred to as path-integration. The respective contribution of landmark and path-integration to place-cell activity in the hippocampus is still unclear and complicated by the fact that the two mechanisms usually overlap. To bias spatial mechanisms toward landmark or path-integration, we use a treadmill equipped with a long belt on which male mice run sequentially through a zone enriched and a zone impoverished in visual-tactile cues. We show that inactivation of the medial septum (MS), which is known to disrupt the periodic activity of grid cells, impairs mice ability to anticipate the delivery of a reward in the cue-impoverished zone and transiently alter the spatial configuration of place fields in the cue-impoverished zone selectively: following MS inactivation, place fields in the cue-impoverished zone progressively shift backward and stabilize near the cues, resulting in the contraction of the spatial representation around cues; following MS recovery, the initial spatial representation is progressively restored. Furthermore, we found that place fields in the cue-rich and cue-impoverished zones are preferentially generated by cells from the deep and superficial sublayers of CA1, respectively. These findings demonstrate with mechanistic insights the contribution of MS to the spread of spatial representations in cue-impoverished zones, and indicate a segregation of landmark-based and path-integration-assisted spatial mechanisms into deep and superficial CA1, respectively.

Key words: CA1 radial axis; landmark; medial septum; path-integration; place cells; treadmill

Significance Statement

Cells encoding a cue-impoverished zone and the vicinity of landmarks responded differentially to septal inactivation and resided in distinct sublayers of CA1. These findings provide new insights on place field mechanisms: septal activity is critical for maintaining the spread of place fields in cue-impoverished areas, but not for the generation of place fields; Following MS inactivation, trial-by-trial network modifications by activity-dependent mechanisms are responsible for the gradual collapse of spatial representations. Furthermore, the findings suggest parallel coding streams for landmark and self-motion information. Superficial CA1 cells are better suited for encoding global position via the assist of path-integration, whereas deep CA1 cells can support spatial memory processes on an object-specific basis.

\section{Introduction}

Since the discovery of place cells in the hippocampus and the introduction of a cognitive map hypothesis (O'Keefe and
Dostrovsky, 1971), an intriguing question is how the selective firing fields of place cells, called "place fields", are generated and controlled by different inputs to the hippocampus. The recent discovery of spatially tuned cells, such as border cells (Solstad et al., 2008), and grid cells (Hafting et al., 2005), in the medial

Correspondence should be addressed to Dr. Sebastien Royer, Center for Functional Connectomics, KIST 5 , Hwarang-ro 14-gil, Seongbukgu, Seoul 02792, Republic of Korea. E-mail: sebiroyer@gmail.com.

DOl:10.1523/JNEUROSCI.3211-17.2018

Copyright $\odot 2018$ the authors $\quad 0270-6474 / 18 / 386766-13 \$ 15.00 / 0$ 
entorhinal cortex (MEC), one of the main input structures to the hippocampus, was a major step toward answering this question. Border cells increase their firing activity in response to boundaries of the environment and convey a spatial input related to external sensory cues (Savelli et al., 2008; Solstad et al., 2008). In contrast, grid cells display several periodic firing fields that provide an intrinsic metric of the environment and are believed to contribute information associated with both environmental cues and path integration (Mittelstaedt and Mittelstaedt, 1980; McNaughton et al., 2006; Moser and Moser, 2008; Krupic et al., 2015; Chen et al., 2016).

Initially, grid cell inputs were hypothesized to be the primary mechanism for place field generation (McNaughton et al., 2006; Solstad et al., 2006; Hayman and Jeffery, 2008; Cheng and Frank, 2011). However, it was recently shown that in pre-weanling rat pups, place fields can exist before the emergence of the grid cell network (Muessig et al., 2015), whereas in adult rats, the disruption of grid cell spatial periodicity by pharmacological inactivation of the medial septum (MS) does not alter preexisting place fields (Brandon et al., 2011; Koenig et al., 2011; but see Wang et al., 2015) nor prevent the emergence of place fields in novel environments (Brandon et al., 2014). In contrast, hippocampal spatial representations remap but remain spatially tuned following inactivations of the MEC that are nonspecific in regard to cell types (Brun et al., 2008; Miao et al., 2015; Rueckemann et al., 2016).

The contribution of path-integration to hippocampal spatial representation is still unclear. Complicating this analysis is the fact that path-integration contribution might vary among hippocampal subregions, as differences in representation are reported along septotemporal (Jung et al., 1994; Kjelstrup et al., 2008; Royer et al., 2010; Ciocchi et al., 2015), proximodistal (Henriksen et al., 2010; Burke et al., 2011), and radial (Mizuseki et al., 2011; Danielson et al., 2016; Geiller et al., 2017) axes, and that path-integration normally coexists with landmark-based mechanisms, making it difficult to distinguish the unique contribution of path-integration. For these reasons, we examined the impact of MS inactivation in diverse locations in the CA1 radial axis and in two different contexts, path-integration alone and landmark-based navigation. We used a nonmotorized treadmill apparatus equipped with a 2-m-long belt (Royer et al., 2012) in which mice ran sequentially through a zone enriched with cues and a zone impoverished in cues and had to use path-integration to stop at a reward position in the cue-impoverished zone. In addition, we took advantage of the vertical arrangement of recording sites in silicon probes to sample various depths of the CA1 pyramidal layer. We found that inactivation of the MS abolished theta oscillations, impaired the ability of mice to estimate the reward position, and mostly altered place fields in the cueimpoverished zone, shifting their position toward the cues in a progressive and reversible manner. Furthermore, we found that the shifted place fields belonged to cells predominantly located in the superficial sublayer of CA1, supporting an organization of path-integration mechanisms along the CA1 radial axis.

\section{Materials and Methods}

Data were collected from eight male C57BL/6 mice aged between 6 and 7 weeks. The mice were housed two or three per cage in a vivarium with $12 \mathrm{~h}$ light/dark cycles. Three mice received muscimol injections. Two mice received saline injections as a control. Three mice received no injections. Training and recording sessions occurred during the light cycles.

All experiments were conducted in accordance with institutional regulations (Institutional Animal Care and Use Committee of the Korea
Institute of Science and Technology), and conformed to the Guide for the Care and Use of Laboratory Animals.

Behavioral apparatus. The treadmill consisted of a 2-m-long light velvet belt resting on two $3 \mathrm{D}$ printed wheels, which the mice moved themselves at will (Fig. 1A; Royer et al., 2012). Because the mice were head-fixed, they remained static relative to room cues as they ran on the treadmill, and the only information useful for place field generation on the belt came from sensory cues coupled to the belt and self-motion cues. A different belt design was used for mice that received and did not received injections. For the five mice that received injections, two cues made of flexible shrink tubes vertically erected $(\sim 2 \mathrm{~cm}$ height $)$ on both edges of the belt were fixed $20 \mathrm{~cm}$ apart and provided visual-tactile stimulation to both sides of the mice. Aside from these cues, the belt was uniform in both color (black) and texture, and was changed before the recording sessions to minimize odorant cues. For the three mice that received no injections, six cues were interspersed on a 2 -m-long belt except for a $80-\mathrm{cm}$-long section that served as cue-impoverished zone. Room cues were concealed using black cardboard panels on both sides of the treadmill. A lick port equipped with two channels, one for delivery and the other for removal (via suction) of water, was constantly held in front of the mouth of the mouse. A LED/photosensor couple at the tip of the lick port was used to detect individual licks.

Behavioral control. The forward and backward movement increments of the treadmill were monitored using two pairs of LED/photosensor couples that read patterns on a disc connected to the treadmill wheel, while the zero position was monitored by a LED/photosensor couple detecting a small hole on the belt. From these signals, mouse position was detected in real time by an Arduino board (Arduino Uno, Arduino), which also controlled the valves for the reward delivery. The signals were also recorded on the digital channels of the electrophysiological recording system.

Behavioral training. The mice were water restricted to $1 \mathrm{ml}$ of water per day, and trained ( $1 \mathrm{~h}$ session per day) to run on the treadmill with their head fixed for 2 weeks. A drop of water was delivered on every trial at the same position on the belt via the lick port. The water was removed from the lick port (via suction) $10 \mathrm{~cm}$ after the position of water delivery, such that mice had to completely stop within a $10 \mathrm{~cm}$ area to consume the water. Mice typically ran without interruption up to the reward location where they stopped for a few seconds to drink, and became expert at this task within a week (Royer et al., 2012; Geiller et al., 2017) such that no learning related to the task was involved on the recording days.

Preparation for head-fixation and cannula implantation. Under isoflurane anesthesia (supplemented by injections of buprenorphine $0.1 \mathrm{mg} /$ $\mathrm{kg}$, s.c.), two small watch screws were driven into the bone above the cerebellum to serve as reference and ground electrodes for the recordings. A plastic headplate with a window opening in the center, which was made in-house (Chung et al., 2017), was cemented to the skull with dental acrylic. The headplate was designed to conveniently attach (and detach) to a holding plate using two screws. For the local muscimol injection, a guide cannula (26G, Plastic One) aimed at the MS was implanted (AP: $+0.8 \mathrm{~mm}, \mathrm{ML}:+1 \mathrm{~mm}, 15^{\circ}$ toward the midline; Wang et al., 2015; Brandon et al., 2014). Mice were allowed to recover for $7 \mathrm{~d}$ before starting behavioral training.

Electrode implantation. Under isoflurane anesthesia, a silicon probe (NeuroNexus Buzsaki32; 4 shanks with 8 recording sites per shank) mounted on a microdrive (Chung et al., 2017) and coated with DiI (molecular probe) was inserted $1 \mathrm{~mm}$ above the pyramidal layer. The microdrive was cemented to the skull and headplate. A mixture of bone wax and mineral oil was used to cover the craniotomy. On the following days, the silicon probe was slowly lowered to the pyramidal layer using the microdrive. A plastic cap was used to protect the microdrive/silicon probe assembly (Chung et al., 2017).

Recordings. A silicon probe with 4 shanks and 8 recording sites per shanks (NeuroNexus Buzsaki32) was used. The recording sites were organized in a staggered configuration that spanned vertically over $140 \mu \mathrm{m}$ and could cover the entire depth of the pyramidal layer. Neurophysiological signals were acquired continuously at $30,000 \mathrm{~Hz}$ on a 250 -channel recording system (Intan Technologies, RHD2132 amplifier board with RHD2000 USB Interface Board, and custom-made LabVIEW user inter- 
A

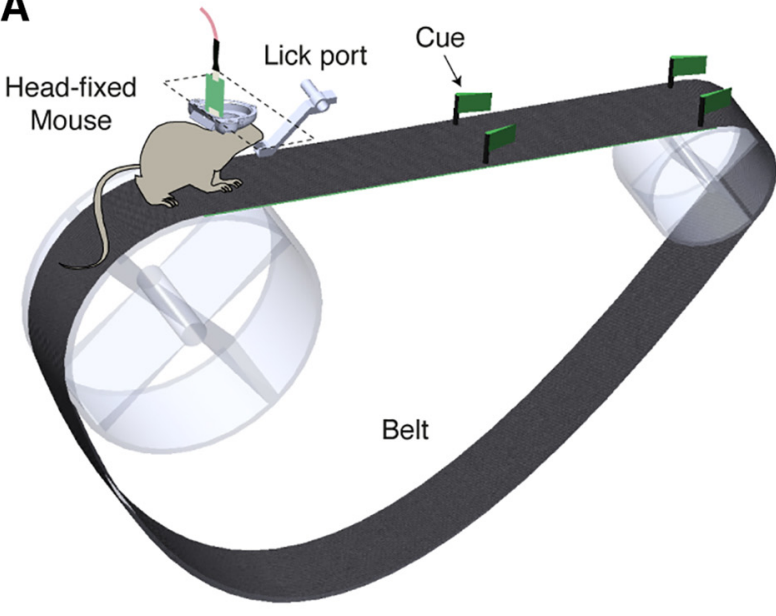

Cue Cue Cue-impoverished Reward

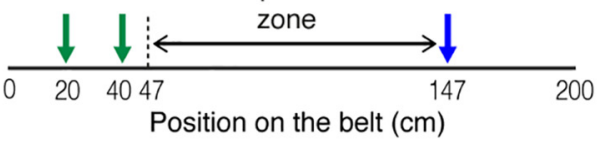

B

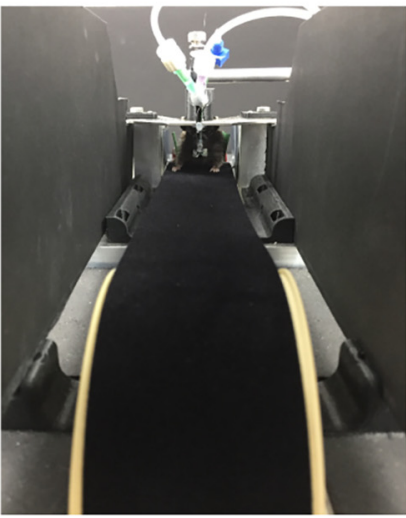

C

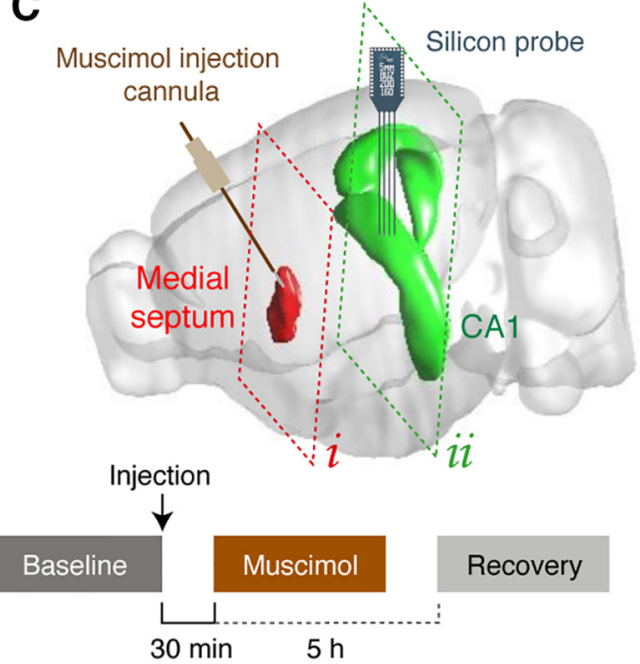

D

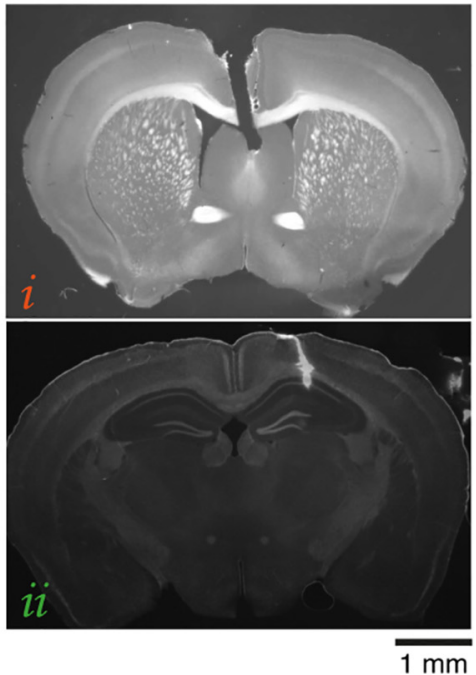

Figure 1. Treadmill apparatus, injection cannula and silicon probe. $\boldsymbol{A}$, Treadmill apparatus (top) and schematics of belt layout showing the position of cues, cue-impoverished zone, and reward (bottom). $\boldsymbol{B}$, Mouse in the cue-impoverished zone (left) and mouse viewpoint within the cues (right). $\boldsymbol{C}$, Top, 3D representation of the mouse brain (Allen brain atlas explorer) showing intended target sites for the injection cannula and silicon probe (the medial septum and the (A1 hippocampal region, respectively). Bottom, Schedule for muscimol injection and recording sessions. Muscimol and recovery sessions were started $30 \mathrm{~min}$ and $5 \mathrm{~h}$ after the injections, respectively. D, Example of coronal sections (DAPI fluorescence image) showing the lesion generated by the cannula ( $\boldsymbol{D i}$ ) and the track (Dil fluorescence) of one shank of the silicon probe (Dii) for one mouse.

face). On the recording day, the three following sessions were performed for three mice: baseline (before injection), muscimol (starting $30 \mathrm{~min}$ after injection), and recovery (starting $5 \mathrm{~h}$ after injection). For two additional mice, saline was injected instead of muscimol. Data included are from 1 recording day per mouse. It is worth mentioning that place field and licking dynamics cannot be explained by a gradual effect of musci$\mathrm{mol}$ diffusion/washout, considering the short time scale of trials $(\sim 10$ s/trial) relative to the $30 / 300 \mathrm{~min}$ postinjection delay period preceding muscimol/recovery sessions.

Intracranial injections. Drug intracranial injections were performed as follows. A dummy cannula was gently removed, cleaned with alcohol, and dipped in sterile mineral oil. An injector cannula (33 Ga, Plastics One) was inserted in the guide cannula, protruding by $1.8 \mathrm{~mm}$, and was connected to a $10 \mu \mathrm{l}$ Hamilton syringe filled with muscimol $(0.125$ $\mathrm{mg} \cdot \mathrm{ml}^{-1}$ ) or saline solutions. Muscimol or saline $(130 \mathrm{nl})$ was injected at rate of $5 \mu \mathrm{l} \cdot \mathrm{h}^{-1}$ using a microinjection pump (KDS 100 Legacy Single Syringe Infusion Pump, KD Scientific).

Spike sorting. The wideband signals were digitally high-pass filtered $(0.8-5 \mathrm{kHz})$ off-line for spike detection or low-pass filtered $(0-500 \mathrm{~Hz})$ and downsampled to $1000 \mathrm{~Hz}$ for local field potentials. Spikes from each shank of the silicon probe were clustered separately with KlustaKwik automatic clustering algorithm (Kadir et al., 2014), using the eight recording sites of each shank and the three first principal components of spike waveforms as features. Spike clusters were then manually adjusted in the program Klusters (Hazan et al., 2006) with the help of built-in functions for autocorrelation, cross-correlation and cluster isolation statistics. Cluster quality measures (L-ratio and isolation distance index; Schmitzer-Torbert et al., 2005; Hazan et al., 2006; Kadir et al., 2014) were implemented in MATLAB (MathWorks). Only clusters with clear refractory periods and well defined cluster boundaries were included in the analyses (Harris et al., 2000).

Histology. The position of electrodes and injection cannula was verified histologically. On the last day of recording, the animals were deeply anesthetized and transcardially perfused with $4 \%$ paraformaldehyde in phosphate buffer. The brain was removed and kept overnight in $4 \%$ paraformaldehyde solution. Coronal sections (100 $\mu \mathrm{m}$ thick) were obtained using a vibratome and mounted on slides using mounting medium with DAPI (Vector Laboratories). Images of DAPI and DiI fluorescence were acquired separately with a Nikon FN1 microscope equipped for fluorescence imaging. 
A

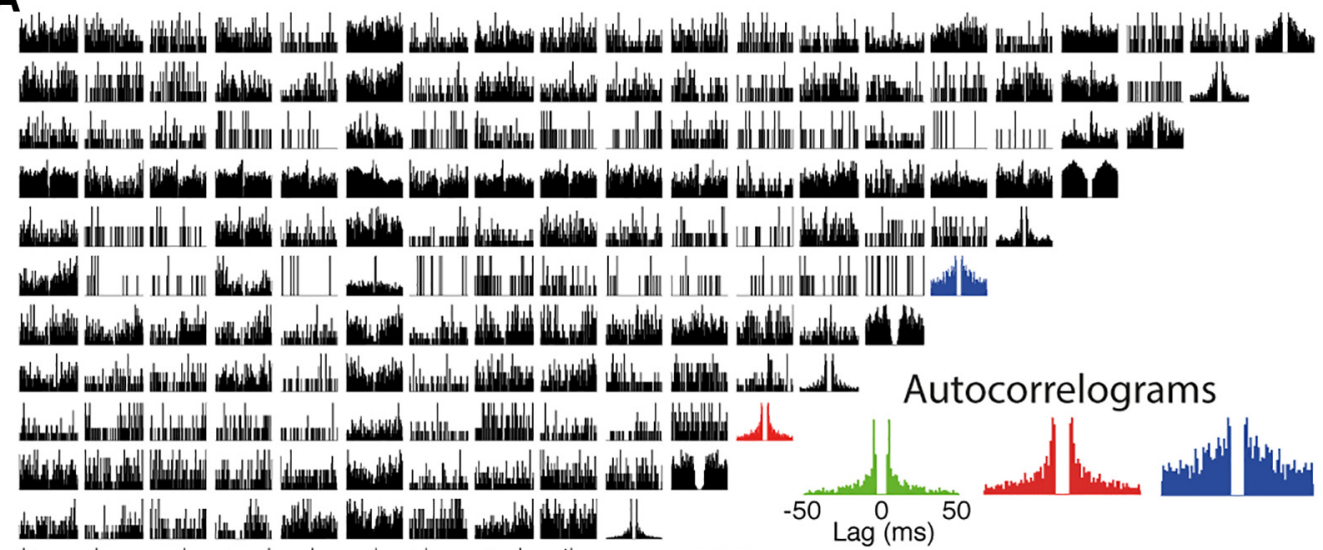

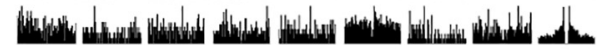

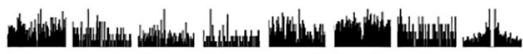

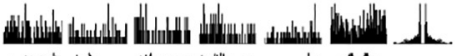

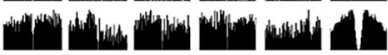

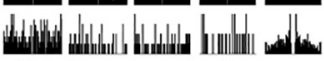

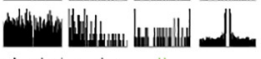

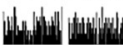
Whith $\|^{-50} \begin{array}{ccc}-50 \\ \operatorname{Lag}(\mathrm{ms})\end{array}$ want hovy

B

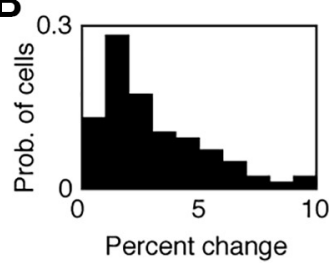

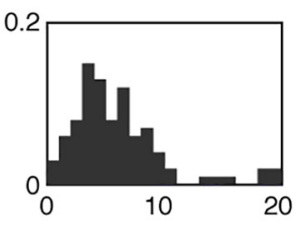

Euclidean distance $(\mu \mathrm{V})$
Silicon

probe

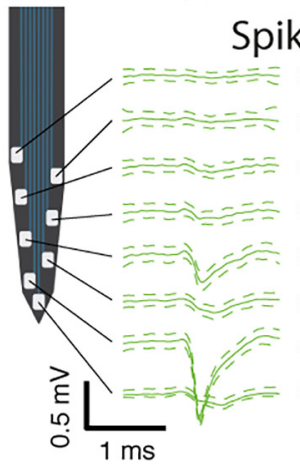

C

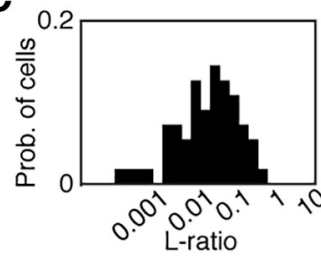

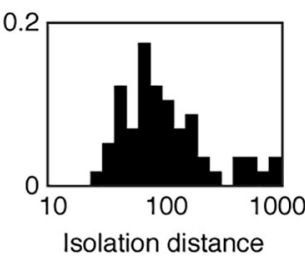

Figure 2. Spike sorting and cluster quality measures. $A$, Examples of autocorrelograms (diagonal) and cross-correlograms for 20 CA1 units recorded simultaneously (top left). Display of autocorrelograms and average ( \pm SD) of unit waveforms for the green, red and blue cells (bottom right). $\boldsymbol{B}$, Comparison between the average spike amplitudes of the first and second halves of all the recording sessions. Percentage change on the channel with the highest amplitude (left) and change in the Euclidean distance between the amplitudes on all the channels (right). $\boldsymbol{C}$, Distribution of L-ratio (left) and isolation distance (right).

Single neuron firing rate vector. The 2-m-long belt was divided into 100 pixels. To generate a firing rate map, the number of spikes discharged in each pixel was divided by the time that the animal spent in the pixel. The firing rate maps were smoothed by convolving a Gaussian function (15 $\mathrm{cm}$ half-height width).

LFP theta power. We selected periods when mouse running speed exceeded $4 \mathrm{~cm} / \mathrm{s}$. The time-frequency spectrogram of the local field potential was computed (Bokil et al., 2010) using a window size of $5 \mathrm{~s}$ and a time step of $1 \mathrm{~s}$, and $1 / f$-corrected. The theta power was taken from the maximum power in the $4-10 \mathrm{~Hz}$ frequency range and was averaged across trials (Schlesiger et al., 2015).

Spatial information. Spatial information was calculated for each cell using the formula, SI $=\Sigma \lambda_{i} / \lambda \times \log _{2}\left(\lambda_{i} / \lambda\right) \times p_{i}$, where SI is the spatial information, $\lambda_{i}$ is the cell's firing rate in bin $i, \lambda$ is the overall mean firing rate of the cell, and $p_{i}$ is the animal occupancy probability of bin $i$ (Skaggs et al., 1996).

Statistical analysis. All statistical analyses were performed in MATLAB (MathWorks). For each distribution, a Kolmogorov-Smirnov test was used to test the null hypothesis that the sample distribution was derived from a standard normal distribution. If normality was uncertain, we used nonparametric tests as stated in the main text or figures. Otherwise, Student's $t$ tests were used to test the sample mean. Correlations were computed using Pearson's correlation coefficient.

\section{Results}

Cue-rich and cue-impoverished zone of the treadmill apparatus

Mice $(n=8)$ were trained to run for water rewards with their head restrained on a nonmotorized treadmill equipped with a 200-cm-long belt for 2 weeks. For the five mice that received injections, two identical cues that provided visual-tactile stimulations and were made with flexible shrink tubes were fixed on the belt $20 \mathrm{~cm}$ apart (Fig. 1A,B). A water reward was delivered through a lick port on every trial (complete belt cycle), at a position $107 \mathrm{~cm}$ after the cues, and was removed via suction $10 \mathrm{~cm}$ later, such that mice had to completely stop within a $10 \mathrm{~cm}$ area to consume the reward. The cue-impoverished zone was defined as the 100-cm-long belt segment between $7 \mathrm{~cm}$ past the cues and the reward position. Indeed, due to the dimensions of the treadmill, the mice could not see the cues until after they passed the reward position; because the head-fixed mice remained static relative to room cues while running, the only information useful for place field generation on the belt came from sensory cues coupled to the belt and from self-motion cues; the belt fabric was uniform in both color (black) and texture, and was changed before the re- 

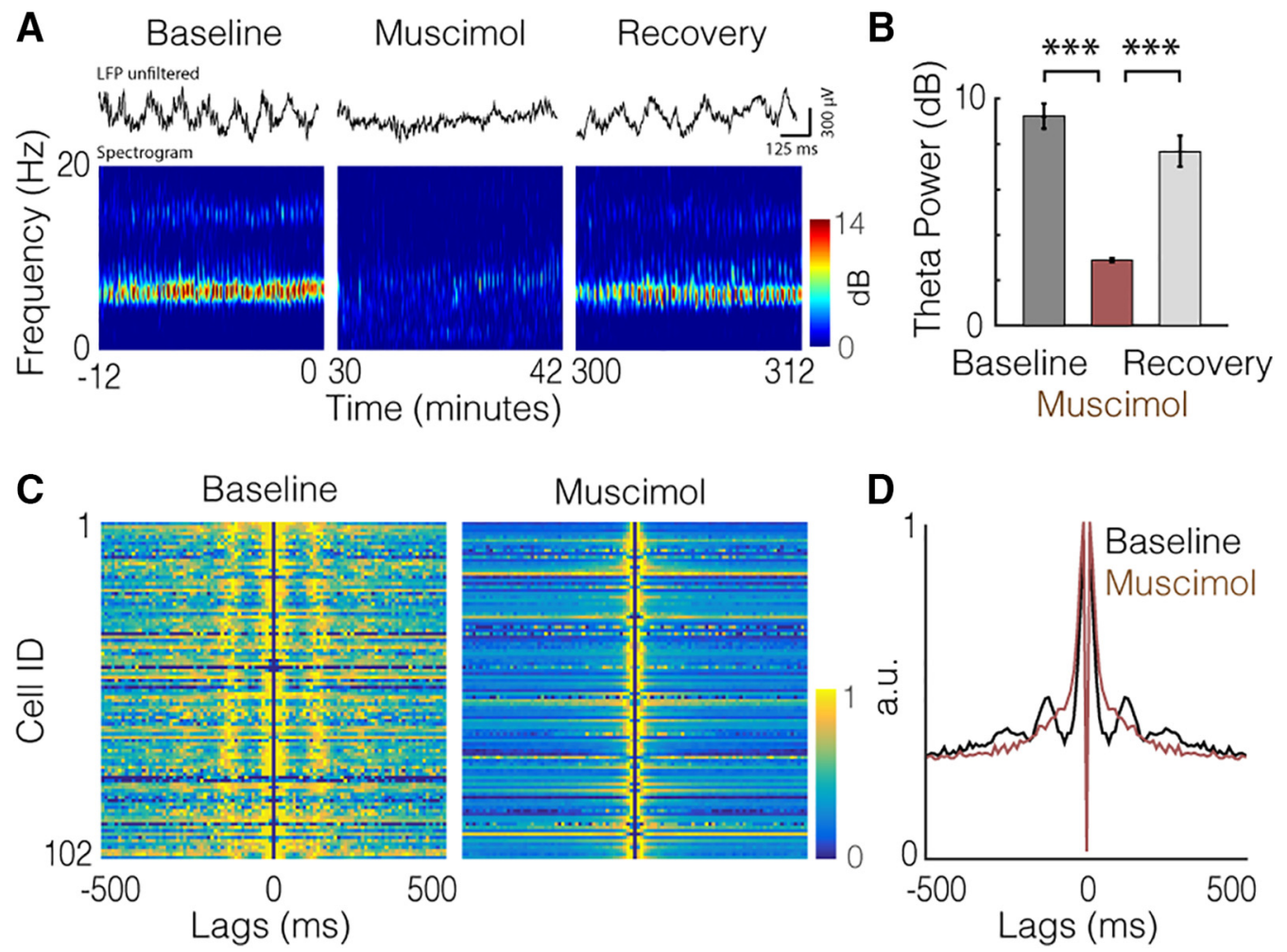

Figure 3. Reduction of theta oscillations by MS inactivation. $\boldsymbol{A}$, Examples of local field potential (LFP) traces (top) and spectrograms (bottom) during baseline (left), muscimol (center), and recovery (right) sessions. $\boldsymbol{B}$, Average LFP theta power $\left({ }^{* * *} p<0.0001\right.$, two-tailed paired $t$ test). $\boldsymbol{C}$, Color-coded representation of cell spike autocorrelograms. The spike autocorrelograms of individual cells are normalized and concatenated in the rows of the matrices. $\boldsymbol{D}$, Average spike autocorrelograms (over the cell population), (a.u., arbitrary units).

cording sessions to minimize odorant cues; against the possibility of residual cues being used, firing fields do not retain fixed positions in belts that completely lack added cues (Koenig and Royer, 2013; Villette et al., 2015). For the three mice that received no injections, six cues were interspersed on the 2-m-long belt except for an $80-\mathrm{cm}$-long section that served as cue-impoverished zone.

\section{Impact of MS inactivation on theta oscillation}

To transiently inactivate the MS, we locally injected the GABA receptor agonist muscimol via a chronically implanted cannula (Brandon et al., 2011, 2014; Koenig et al., 2011; Wang et al., 2015; Fig. $1 C, D)$. To record neuronal activity, a silicon probe (NeuroNexus Buzsaki32; 32 channels, 4 shanks) was chronically implanted in CA1 (Fig. 1C,D). On the day of the experiment, the following three recording sessions were performed: a "baseline" session before muscimol injection; a "muscimol" session that started 30 min after muscimol injection; and a "recovery" session $5 \mathrm{~h}$ after muscimol injection. We recorded a total of 1063 neurons in 8 mice ( 1 recording day per mouse; $n=195,99$ and 133 neurons for muscimol-injected mice; $n=122$ and 138 for salineinjected mice; $n=201,124$, and 51 for mice that received no injection) following standard criteria for unit detection and clustering (Harris et al., 2000; Schmitzer-Torbert et al., 2005; Hazan et al., 2006; Kadir et al., 2014; Fig. 2). As expected from previous studies (Winson, 1978; Brandon et al., 2014; Wang et al., 2015), muscimol-induced inactivation of the MS substantially reduced theta $(6-10 \mathrm{~Hz})$ oscillations in the hippocampus, which was apparent in both local field potential oscillations (Fig. $3 A, B ; 68.8 \pm$ $0.24 \%$ reduction; 12 recording shanks, $t_{(11)}=7.5, p=1.07 \mathrm{e}-5$, paired $t$ test) and CA1 pyramidal cell theta modulation (Fig. $3 C, D)$.

\section{Impact of MS inactivation on mouse behavior}

Next, we examined the effect of MS inactivation on mouse behavior. Consistent with previous reports (Brandon et al., 2014; Wang et al., 2015), mouse running speed was reduced on average (Fig. 4A; baseline, $23.25 \pm 1.4 \mathrm{~cm} / \mathrm{s}$; muscimol, $16.5 \pm 0.9 \mathrm{~cm} / \mathrm{s}$; 75 trials, $t_{(74)}=16.9, p=1.6 \mathrm{e}-27$, paired $t$ test). Additionally, the ability of the mice to estimate the reward position became impaired, which was evidenced by changes in the profiles of running speed and licking behavior. Under the baseline condition, deceleration was detectable within the $20 \mathrm{~cm}$ area preceding the reward position, with the running speed decreased by $34.5 \pm$ $0.8 \%$ between positions 20 and $1 \mathrm{~cm}$ before reward onset (Fig. $4 B$; from $15.4 \pm 0.5 \mathrm{~cm} / \mathrm{s}$ to $10.1 \pm 0.4 \mathrm{~cm} / \mathrm{s} ; t_{(74)}=8.39, p=4 \mathrm{e}-12$, paired $t$ test). Following muscimol injection, such early deceleration was not observed (Fig. $4 B$; from $15.16 \pm 0.63 \mathrm{~cm} / \mathrm{s}$ to $14.03 \pm 0.56 \mathrm{~cm} / \mathrm{s} ; t_{(74)}=-1.76, p=0.08$, paired $t$ test $)$. The mice still stopped at the reward position as they could presumably hear sounds associated with reward delivery and/or sense the water in the lick port, but the stop position was delayed by $5.1 \pm$ $0.1 \mathrm{~cm}$ compared with the baseline condition $\left(t_{(74)}=4.61, p=\right.$ $1.3 \mathrm{e}-05$, paired $t$ test). Likewise, under the baseline condition, the probability of licking was mostly zero in positions distant from the reward position and showed an increase as mice approached the reward. Indicative of anticipation of the reward, the onset of lickings preceded the position of the reward by tens of centimeters (Fig. 4C, black arrow). However, after muscimol injection, licking became less specific to the reward and only increased after the reward was delivered (Fig. $4 C$, brown arrow). As a result, the position with the maximum licking probability was delayed by $4.5 \pm 0.2 \mathrm{~cm}\left(t_{(74)}=5.08, p=4 \mathrm{e}-06\right.$, paired $t$ test $)$ compared with the baseline condition. Interestingly, licking pat- 
A

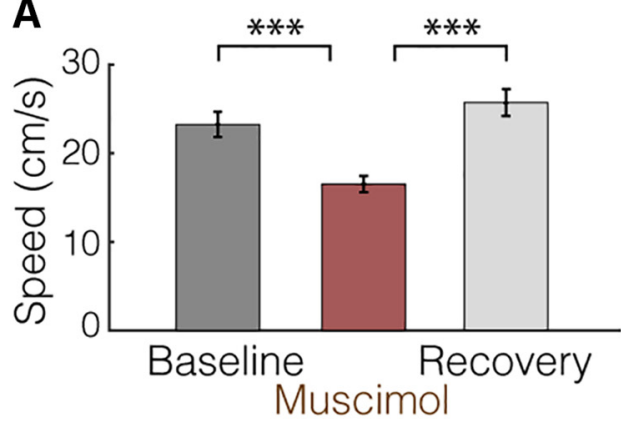

B
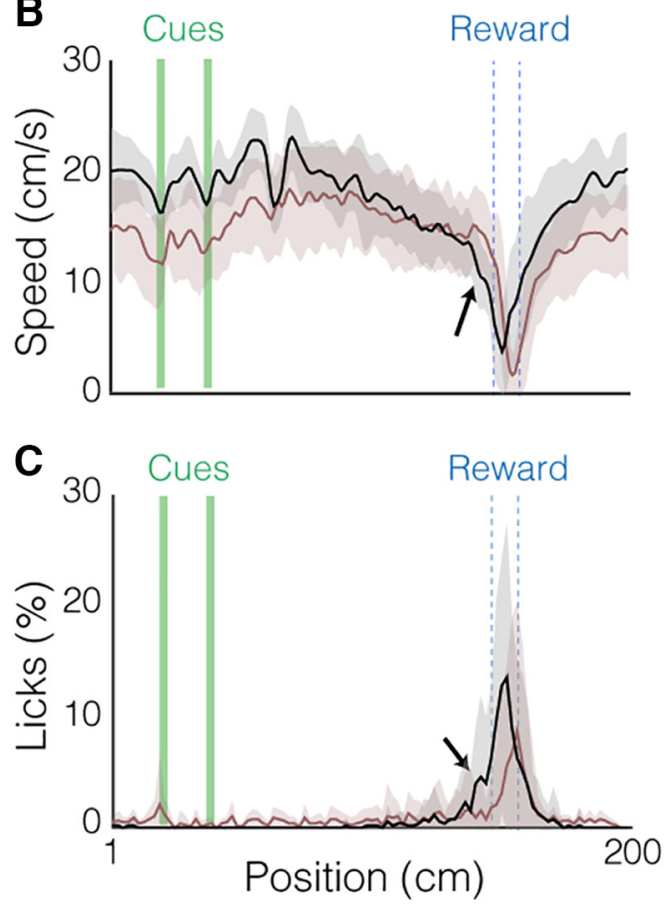

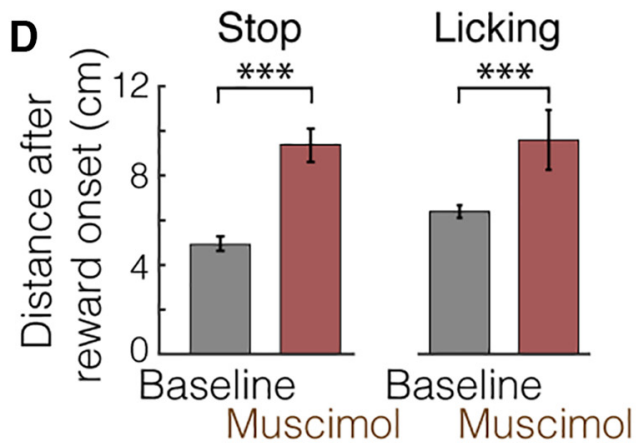

E

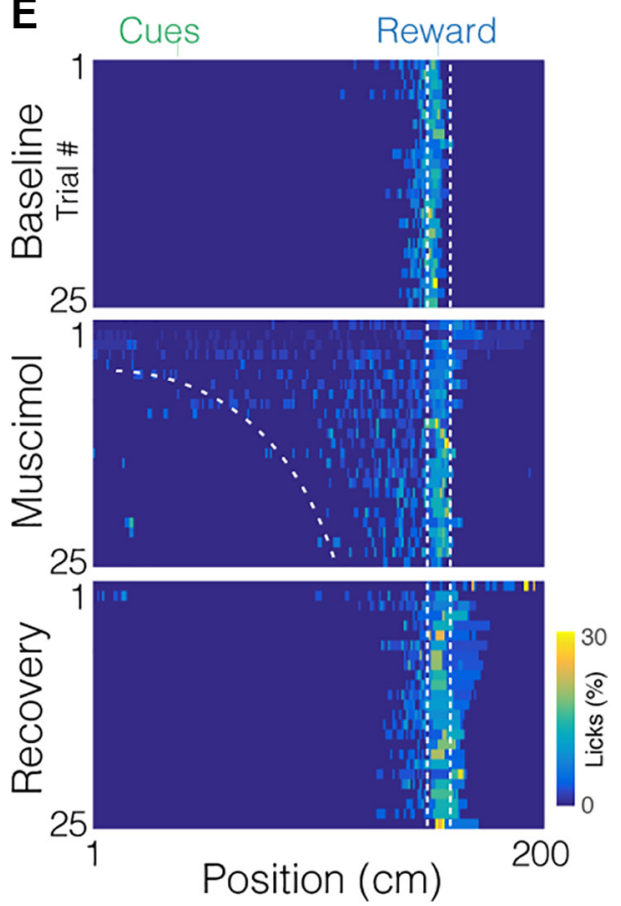

Figure 4. Impact of MS inactivation on mice behavior. A, Average running speed. Two-tailed paired $t$ test, ${ }^{* * *} p<0.0001$. $\boldsymbol{B}$, Spatial profile of running speed (line, average; shadow, SD) for baseline (black) and muscimol (brown) sessions, for one mouse. The arrow indicates mouse deceleration before the reward. $C$, Lick probability (line, average; shadow, SD) for baseline (black) and muscimol (brown) sessions. The arrow indicates the onset of anticipatory lickings in the baseline session. D, Distance from reward onset for speed minimum (left) and licking maximum (right) positions. Two-tailed paired $t$ test, ${ }^{* * *} p<0.0001$. $E$, Evolution of licking behaviors across trials. The curved dash line outlines the progression of the licking pattern. The white dashed lines indicate the onset and removal positions of the reward.

terns showed a progression over trials (Fig. $4 E$ ): on the first muscimol trial, anticipatory lickings were relatively concentrated near the reward $(147<X<157, z=8.6, p=3.68 \mathrm{e}-10$, binomial test); over the next trials, lickings were initially spread throughout the belt (trials $2-9,147<X<157, z=1.02$, $p=0.15$, binomial test) and became progressively restricted to the late portion of the cue-impoverished zone (trials $10-25,47<X<107, z=$ $-3.8, p=4.05 \mathrm{e}-06$, binomial test), suggesting that mice could progressively learn to avoid licking mistakes in the early portion of the cue-impoverished zone but remained impaired in the late portion.

\section{Rate map correlation: non-remapping versus remapping cells} Next, we examined the effect of MS inactivation on place field activity by implementing raster and rate map plots of individual cells for baseline, muscimol and recovery sessions (Fig. 5). Based upon visual inspection, cells encoding the cue-impoverished zone (Fig. $5 A$ ) were more affected by the muscimol injections than cells encoding the cues (Fig. $5 B$ ). To quantify this phenomenon, we calculated the spatial correlation between the baseline and muscimol rate maps for each cell, considering cells with stable firing fields during the baseline condition (i.e., with a spatial correlation exceeding 0.5 between the first and second halves of the sessions, $n=102$ cells; $n=35,29$ and 38 cells for each mouse; Fig. 6A). On average, cells with place field peaks located inside the cue-impoverished zone showed lower correlation coefficients than cells outside the cue-impoverished zone (Fig. $6 B$; cue-impoverished zone, $r=0.13 \pm 0.05, n=63$; non-cue-impoverished zone, $r=0.42 \pm 0.07, n=39$; unpaired $t$ test, $\left.t_{(100)}=-3.87, p=1.97 \mathrm{e}-04\right)$, which was not explained by an intrinsic difference in field stability because the stability of place fields inside and outside the cueimpoverished zone was not significantly different under the baseline condition (Fig. 6A; cue-impoverished zone, $r=$ $0.82 \pm 0.02$; non-cue-impoverished zone, $r=0.83 \pm 0.02$; unpaired $t$ test, $\left.t_{(100)}=-0.43, p=0.69\right)$, and no difference was observed for mice injected with saline (Fig. 6C; cueimpoverished zone, $r=0.77 \pm 0.03, n=43$; non-cueimpoverished zone, $r=0.79 \pm 0.03, n=28$; unpaired $t$ test, $t_{(67)}=-0.78, p=0.41 ; n=34$ and 37 cells for each mouse). 

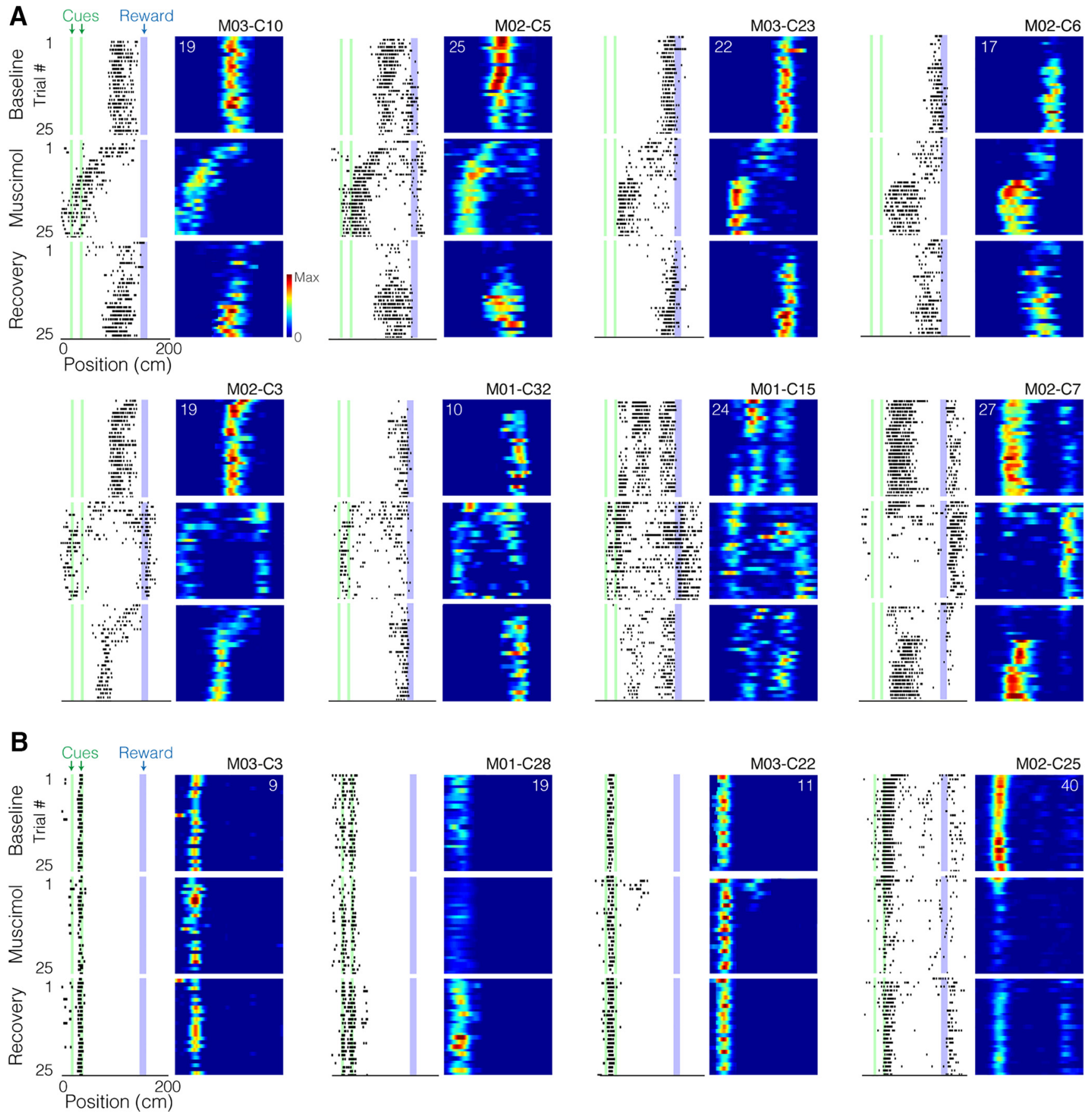

Figure 5. Examples of cells with place field located within and outside the cue-impoverished zone. $A$, Examples of cells having place fields inside the cue-impoverished zone. For each, spike raster plots (left) and firing rate maps (right) are shown for single trials of baseline (top), muscimol (middle), and recovery (bottom) sessions. White numbers on the color-coded plots indicate cells peak firing rates. Mouse ID and cell number are indicated above the color-coded plots. $\boldsymbol{B}$, Same as $\boldsymbol{A}$ for examples of cells with place fields outside the cue-impoverished zone.

Then we divided the cell population into three equal groups based on the correlation coefficients (baseline versus muscimol), considering the higher third $(R>0.59)$ as 'non-remapping' cells and the lower third $(R<0.1)$ as "remapping" cells (Fig. $6 D)$. Field peak rate was reduced equally in non-remapping and remapping cell [Fig. $6 E, G$; non-remapping, $35 \%$ reduction from $8.14 \pm 1.29 \mathrm{~Hz}$ (baseline) to $5.25 \pm 0.86 \mathrm{~Hz}$ (muscimol), $t_{(33)}=2.55, p=0.01$; remapping, $33 \%$ reduction from $7.39 \pm 1.1 \mathrm{~Hz}$ (baseline) to $4.9 \pm 0.57 \mathrm{~Hz}$ (muscimol), $t_{(33)}=2.60, p=0.01$, paired $t$ test $]$. Spatial information was also decreased in both cell groups, but the reduction was larger in remapping cells [Fig. 6F, H; non-remapping, 38\% reduction from
$1.04 \pm 0.09 \mathrm{bits} / \mathrm{spike}$ (baseline) to $0.64 \pm 0.09 \mathrm{bits} / \mathrm{spike}$ (musci$\mathrm{mol}), t_{(33)}=4.97, p=2.88 \mathrm{e}-05$; remapping, $52 \%$ reduction from $0.85 \pm 0.09 \mathrm{bits} / \mathrm{spike}$ (baseline) to $0.40 \pm 0.06 \mathrm{bits} / \mathrm{spike}$ (musci$\mathrm{mol}), t_{(33)}=4.01, p=0.0003$, paired $t$ test $]$. Finally, a striking difference between the two groups was a significant shift in place field positions for remapping cells but not for non-remapping cells (Fig. 6I; shift of field peak: remapping, $66.85 \pm 1.98 \mathrm{~cm}, z=3.48, p=$ $4.99 \mathrm{e}-04$; non-remapping, $6.22 \pm 2.46 \mathrm{~cm}, z=0.28, p=0.77$, Wilcoxon signed rank test). The trends observed for spatial correlations, peak rates, spatial information and place field shifts were consistent across individual animals (Fig. $6 J-M$ ). 
A

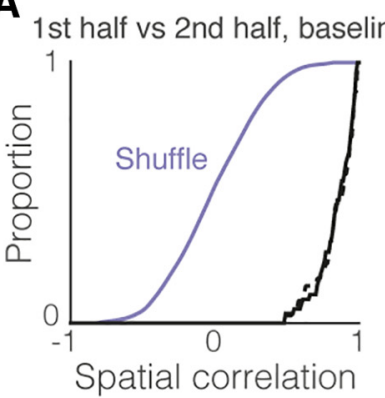

D Remapping Non-Remapping
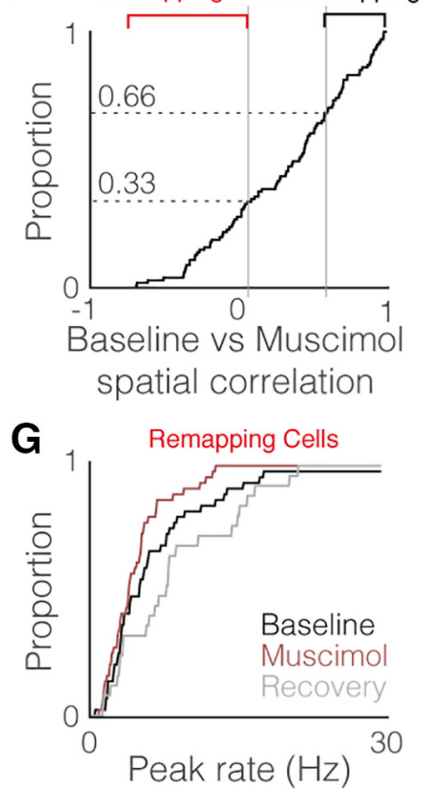

B Baseline vs Muscimol Baseline vs Recovery

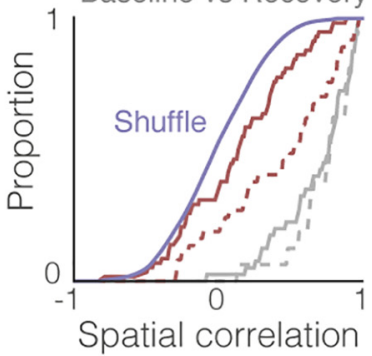

E
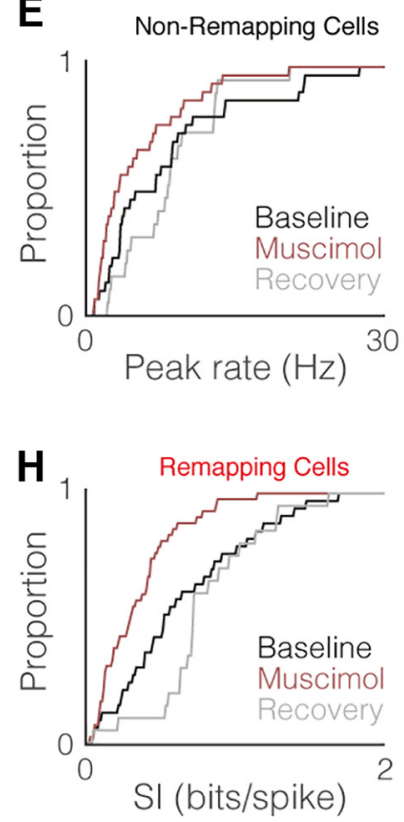

C Baseline vs Saline

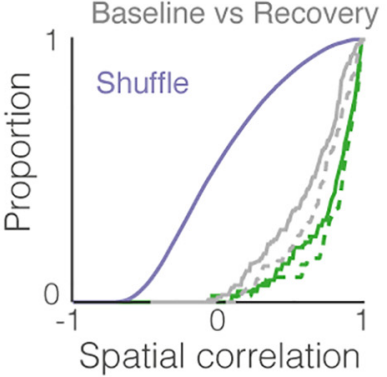

F
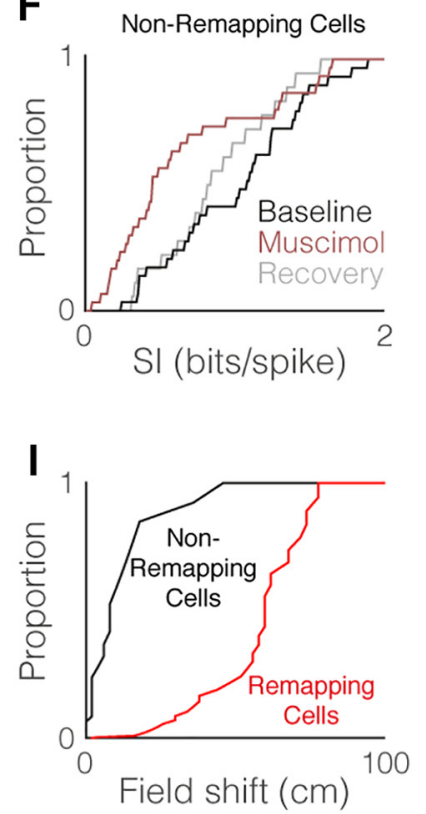
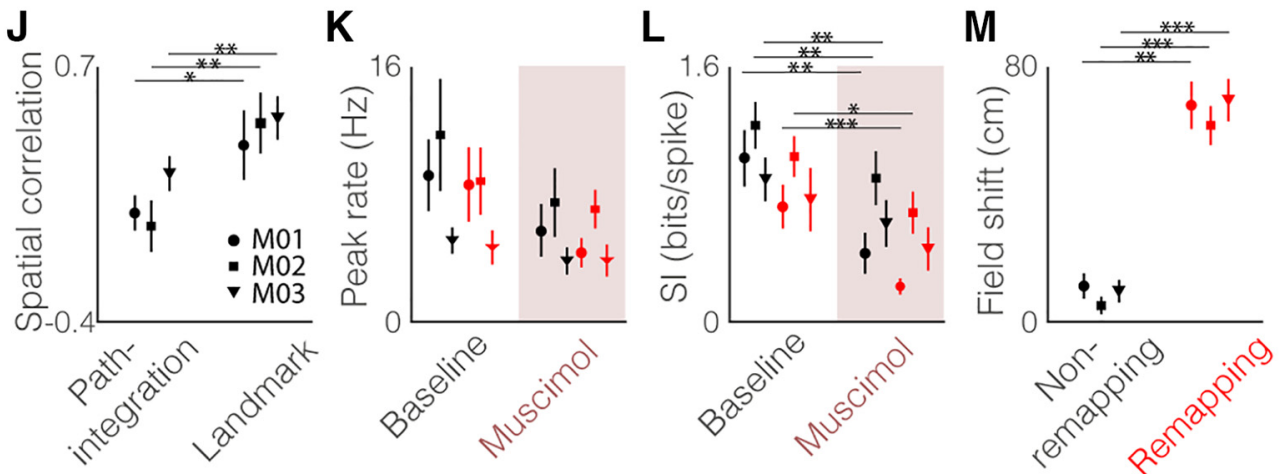

Figure 6. Spatial correlations and field characteristics of non-remapping and remapping cells. $\boldsymbol{A}$, Cumulative distribution of rate map correlations between first and second halves of baseline session (black), for cells within (plain) and outside (dash) the cue-impoverished zone and for 10,000 shuffles of the field position (purple). $\boldsymbol{B}$, Cumulative distribution of rate map correlations between baseline and muscimol sessions (brown), and between baseline and recovery sessions (gray), for cells within (plain) and outside (dash) the cue-impoverished zone. $\boldsymbol{C}$, Same as $\boldsymbol{B}$ for experiments where saline was injected instead of muscimol. $\boldsymbol{D}$, Cumulative distribution of rate map correlations between baseline and muscimol sessions, and threshold criteria defining non-remapping and remapping cells. $\boldsymbol{E}, \boldsymbol{F}$, Cumulative distributions of non-remapping field peak firing rates $(\boldsymbol{E})$ and spatial information $(\boldsymbol{F})$, for baseline (black), muscimol (brown) and recovery (gray) sessions. $\boldsymbol{G}, \boldsymbol{H}$, Same as $\boldsymbol{E}$ and $\boldsymbol{F}$ for remapping cells. $\boldsymbol{I}$, Shift in place field positions for remapping cells but not for non-remapping cells (shift of field peak: remapping, $66.85 \pm 1.98 \mathrm{~cm}, p=4.99 \mathrm{e}-04$; non-remapping, $6.22 \pm 2.46 \mathrm{~cm}, p=0.77$, Wilcoxon signed rank test). $J$, For each mouse (circle, Mouse 1; square, Mouse 2; triangle, Mouse 3), rate map correlations (mean \pm SEM) between baseline and muscimol sessions for cells within (left) and outside (right) the cue-impoverished zone $\left({ }^{*} p<0.05,{ }^{* *} p<0.01\right.$, two-tailed unpaired $t$ test). $\boldsymbol{K}$, For each mouse, peak rates (mean \pm SEM) for remapping (red) and non-remapping (black) cells, during baseline (left) and muscimol (right) sessions (all baseline vs muscimol, $p>0.05$; paired $t$ test). $L$, For each mouse, spatial information (mean \pm SEM) for remapping (red) and non-remapping (black) cells, during baseline (left) and muscimol (right) sessions $\left({ }^{*} p<0.05,{ }^{* *} p<0.01,{ }^{* *} p<0.005\right.$, two-tailed paired $t$ test). $\boldsymbol{M}$, For each mouse, place field shifts (mean \pm SEM) for remapping (red) and non-remapping (black) cells $\left({ }^{* * *} p<0.00001\right.$, two-tailed paired $t$ test).

Shifts of remapping cell activity toward the cues

We next determined how different parts of the belt were preferentially encoded by non-remapping and remapping cells. For this analysis, we calculated the proportion of firing activity through- out the belt for each cell, and computed the averages for non-remapping and remapping cell populations separately. As expected from our previous results, non-remapping and remapping cells showed significantly different profiles of activity under 
A
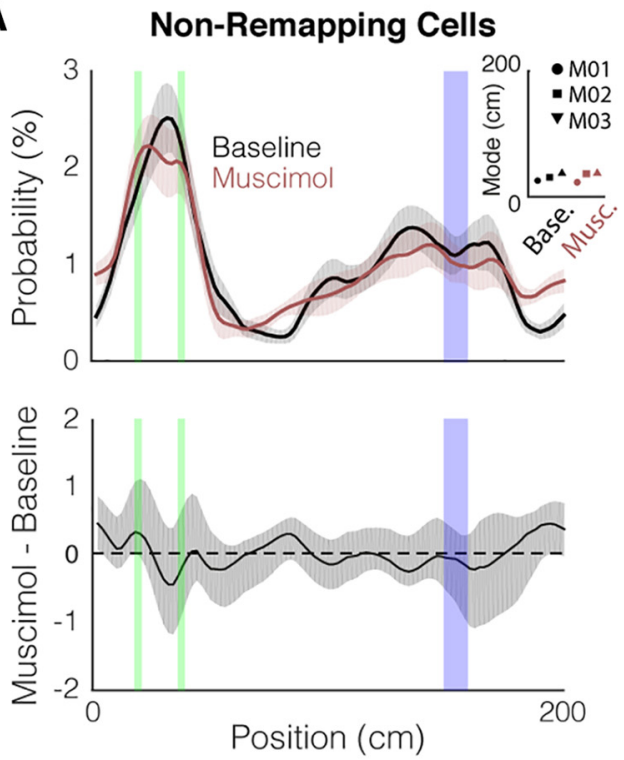

C

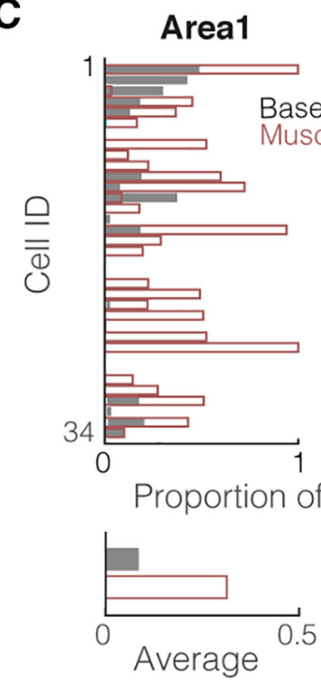

D

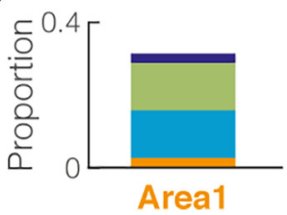

B

Remapping Cells
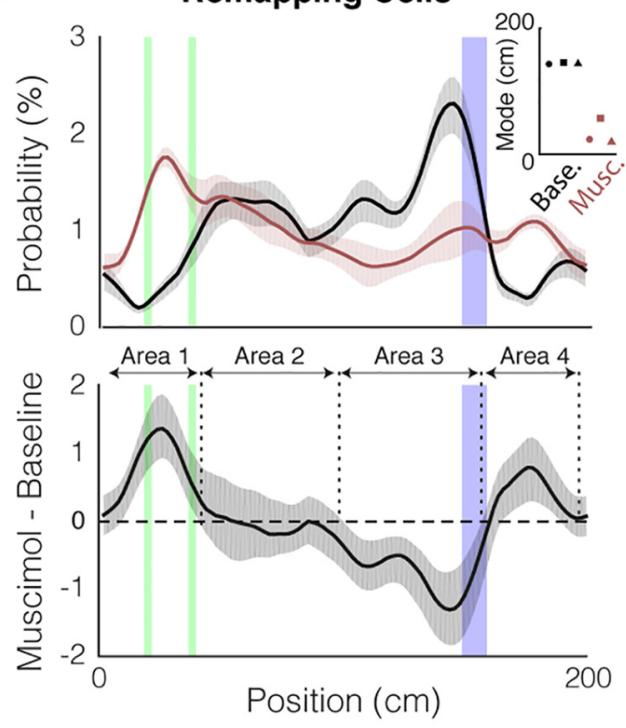

Area 3

Area 4
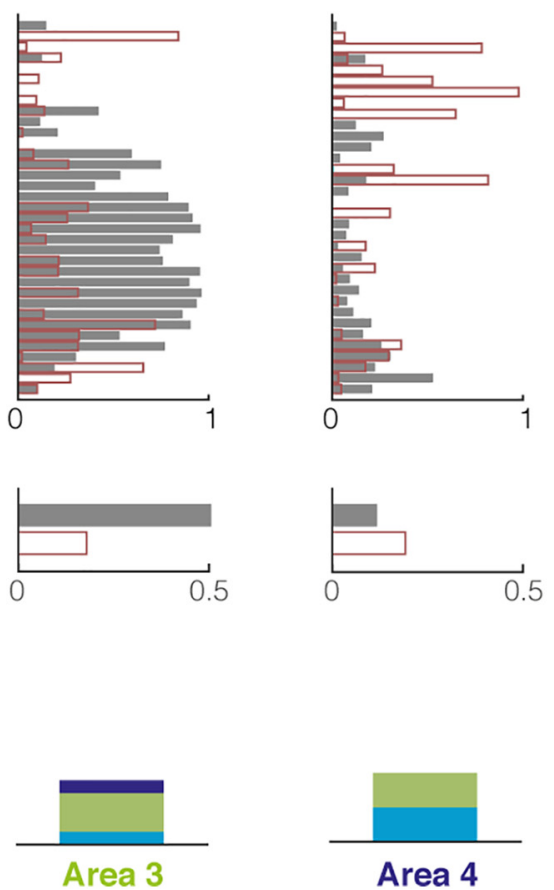

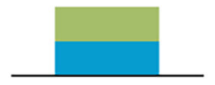

Area 4

Figure 7. Spatial reconfiguration pattern of non-remapping and remapping cells. $\boldsymbol{A}, \boldsymbol{B}$, Top, Average spatial representation (line, average; shadow, SEM) under baseline (black) and muscimol (brown) conditions, for non-remapping $(\boldsymbol{A})$ and remapping $(\boldsymbol{B})$ cell populations. Insets, Position of the mode of each mouse average spatial representation, for baseline and muscimol (brown) conditions. Bottom, Difference between muscimol and baseline representations, and division of the belt in four areas. C, Proportion of firing activity in Areas $1-4$ for individual remapping cells (top) and for the average remapping cell population (bottom). $\boldsymbol{D}$, For each area, the proportional contribution to firing activity (under muscimol) depending on cells' place field locations during baseline condition (color-code). Colors indicate the location of place fields during the baseline session: orange, Area 1; light blue, Area 2; green, Area 3; dark blue, Area 4. Notice that cells encoding initially Area 3 (green) migrated mostly to Area 2, whereas cells encoding initially Area 2 (light blue) migrated to Areas 1 and 4, i.e., the activity shift backward in average.

baseline conditions (Fig. 7 A, B; two-sample Kolmogorov-Smirnov test, $z=0.21, p=3.2 \mathrm{e}-04)$. Most non-remapping cell activity $(57 \%)$ was outside the cue-impoverished zone, with the mode matching the position of the cues. In contrast, most remapping cell activity $(71 \%)$ was concentrated in the cue-impoverished zone, with the mode at the end of the cue-impoverished zone just before the reward delivery position. However, under the muscimol condition, the profiles became more similar, with the mode of remapping cell activity shifting to the cue location (Fig. $7 B$, top), and only $43 \%$ of remapping cell activity remained in the cue- impoverished zone, whereas the non-remapping cell profile was unchanged (Fig. 7A, top; two-sample Kolmogorov-Smirnov test, $z=0.08, p=0.55$ ).

Although no difference was visible for non-remapping cells after baseline-muscimol subtraction (Fig. 7A, bottom), four areas could be detected for remapping cells (Fig. $7 B$, bottom). Outside the cue-impoverished zone, the cue-rich area (Area 1) and the area just after the reward (Area 4) showed an increase in overall representation. Within the cue-impoverished zone, the initial part showed no change in representation (Area 2), whereas the 

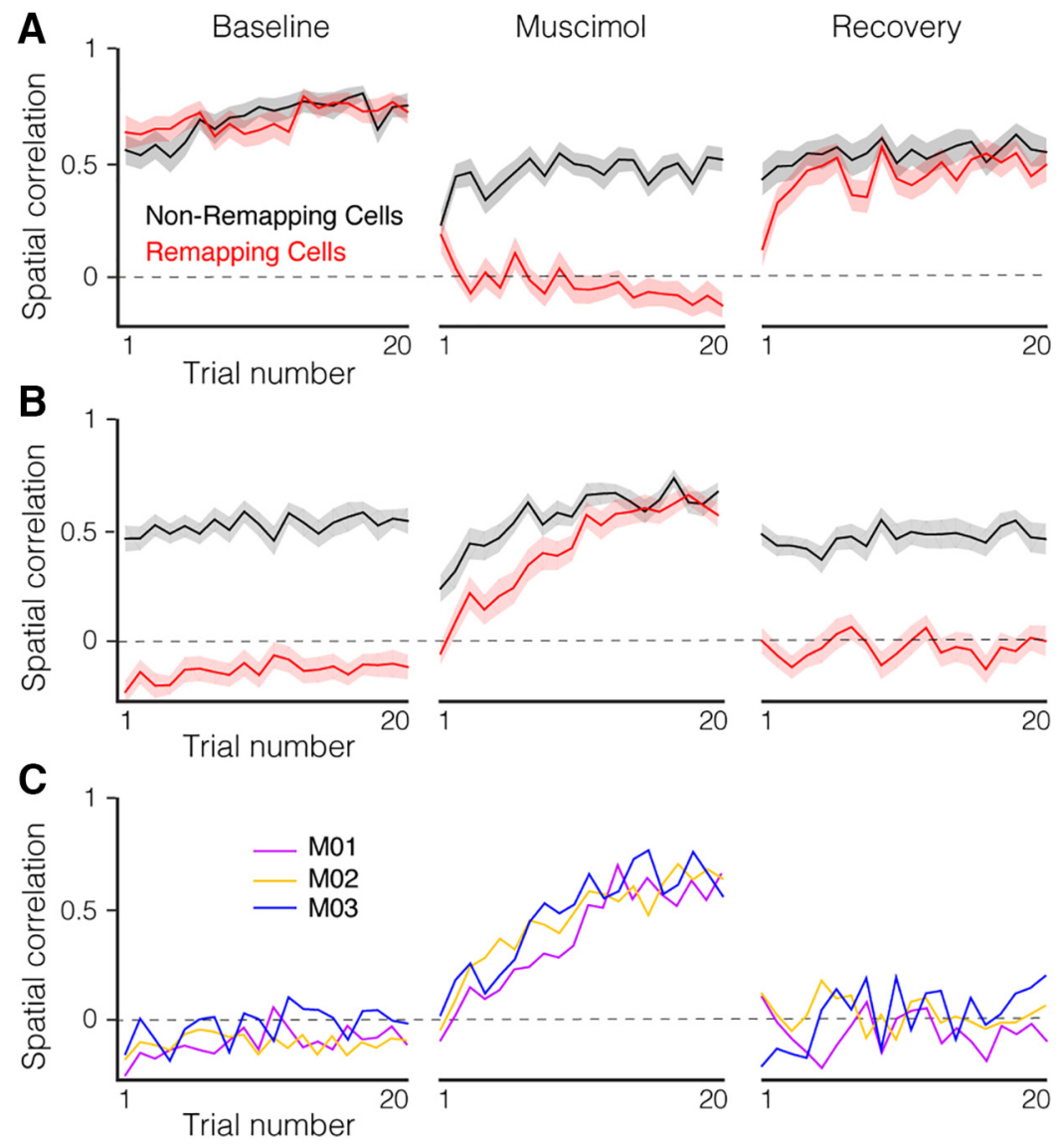

Figure 8. Temporal dynamic of non-remapping and remapping cells. $A$, Evolution of rate map correlations across trials, for non-remapping (black) and remapping (red) cell populations (line, average; shadow, SEM). The 10 last trials of the baseline session are used to implement a reference rate map, which is correlated with individual trials. $\boldsymbol{B}$, Same as $\boldsymbol{A}$ except that the 10 last trials of the muscimol session were used as reference. $\boldsymbol{C}$, Same as $\boldsymbol{B}$ for individual mouse and only remapping cells.

later part showed a decrease in representation (Area 3). We computed the representation of each remapping cell by area for baseline and muscimol conditions (Fig. 7C) and the average migration of activity by area (Fig. 7D). On average, remapping place fields shifted in the backward direction in an orderly manner, with fields encoding Area 3 shifting toward Areas 2 and 1 ( $15 \%$ vs $46 \%$ and $22 \%$ representation in Area 4 vs Areas 2 and 1, respectively; $z=2.42, p=0.0064$, binomial test), and fields from Area 2 shifting toward Areas 1 and 4 (11\% vs $44 \%$ and $32 \%$ representation in Area 3 vs Areas 1 and 4, respectively; $z=2, p=$ 0.02 , binomial test). In summary, remapping fields relocated near the cues through shifts in the backward direction.

\section{Dynamic of spatial reorganization}

Several cells showed progressive backward drifts of place fields during the muscimol session (Fig. 5A), suggesting that the spatial reorganization was a progressive process occurring over several trials. To quantify the temporal dynamics of non-remapping and remapping cell populations, we computed the spatial correlation of single trials using the last 10 trials of either the baseline session or the muscimol session as a reference and calculated the average of the cell population for each trial (Fig. $8 A-C$ ). Interestingly, the impact of muscimol injection could be divided into two phases. Initially, both non-remapping and remapping cell populations showed an immediate reduction in spatial correlation referenced to baseline (Fig. 8A; non-remapping, $t_{(33)}=4.51, p=$ $7.54 \mathrm{e}-05$; remapping, $t_{(33)}=6.52, p=2.05 \mathrm{e}-07$, paired $t$ test). Then they showed opposite evolutions, non-remapping cells becoming more similar to the baseline condition and remapping cells becoming more different (Trial 20: non-remapping versus remapping, $t_{(66)}=9.3, p=3.45 \mathrm{e}-14$, unpaired $t$ test). The gradual nature of the process was illustrated by the progressive increase in the spatial correlation referenced to the end of muscimol sessions, reaching asymptotic levels after 4 and 9 trials for non-remapping and remapping cells, respectively (Fig. $8 B, C$; non-remapping: Trials $1-4$ vs $20, p<0.005$, Trial 5 vs 20 , $t_{(33)}=-1.6, p=0.11$; remapping: Trials $1-9$ vs $20, p<0.04$, Trial 10 vs $20, t_{(33)}=$ $-0.04, p=0.9$; paired $t$ test). Similarly, the effect of the $5 \mathrm{~h}$ recovery period was gradual for remapping cells, with the average correlation initially lower than nonremapping cells $\left(t_{(45)}=3.97, p=\right.$ $2.97 \mathrm{e}-4$, unpaired $t$ test) but reaching a similar level after 3 trials $\left(t_{(45)}=1, p=\right.$ 0.32 , unpaired $t$ test). Hence, both alteration and restoration of spatial representations, happening during muscimol and recovery sessions, respectively, were gradual processes that spanned over several trials.

\section{Path-integration-associated cells occupy the superficial sublayer of CA1} Several recent studies have shown that place cells in the deep and superficial sublayers of CA1 differ in many respects, such as intrinsic firing properties, phase relationship to theta oscillations, participation in ripple activity, and encoding of rewards and landmarks (Mizuseki et al., 2011; Valero et al., 2015; Danielson et al., 2016; Geiller et al., 2017). Of particular interest, cells in superficial CA1 are more likely to encode unique positions of a treadmill belt that displays repetitions of identical landmarks (Geiller et al., 2017), which could be explained by a larger contribution of path-integration mechanisms in superficial CA1. To test whether remapping and nonremapping cells were located in different regions along the CA1 radial axis, we estimated the position of each cell relative to the middle of the pyramidal layer by measuring the vertical distance between the recording site with the largest spike amplitude and the recording site with maximum ripple power (Fig. 9A; Ylinen et al., 1995; Mizuseki et al., 2011; Geiller et al., 2017). We found that remapping and non-remapping cells were located in distinct depths of the CA1 pyramidal layer, with remapping cells predominantly located in the superficial sublayer (closer to the stratum radiatum), and non-remapping cells predominantly located in the deep sublayer (closer to the stratum oriens; Fig. 9B; remapping, $7.22 \pm 2.54 \mu \mathrm{m}$; non-remapping, $-4.70 \pm 2.61 \mu \mathrm{m} ; t_{(62)}=$ $-2.24, p=0.02$, unpaired $t$ test). The same trend was seen when considering cells that encoded the cue-impoverished zone versus the cued zone with disregard to their response to MS inactivation, further demonstrating that cells in the superficial sublayer are more inclined to use path-integration (Fig. 9C; cueimpoverished zone, $6.93 \pm 1.06 \mu \mathrm{m}$; cued zone, $-7.4 \pm 1.05 \mu \mathrm{m}$, $t_{(180)}=-4.44, p=1.5 \mathrm{e}-05$, unpaired $t$ test; the data from 3 
A

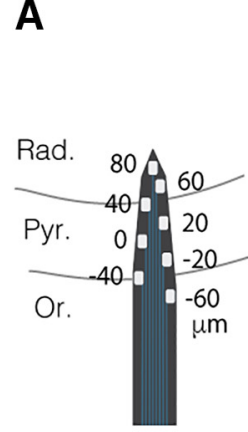

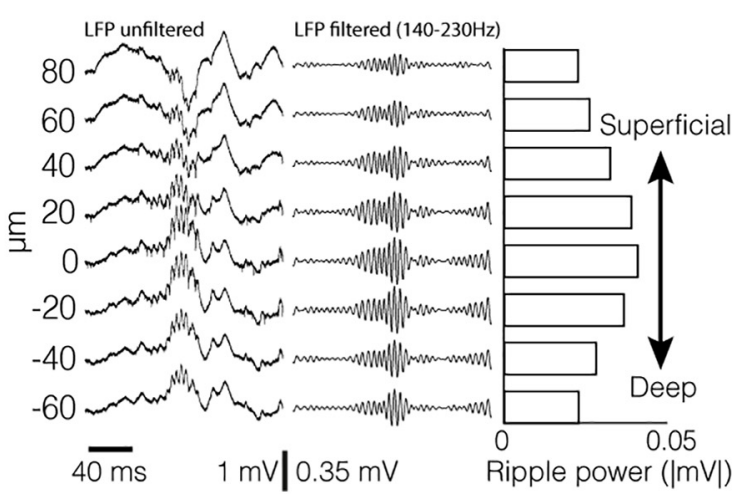

B

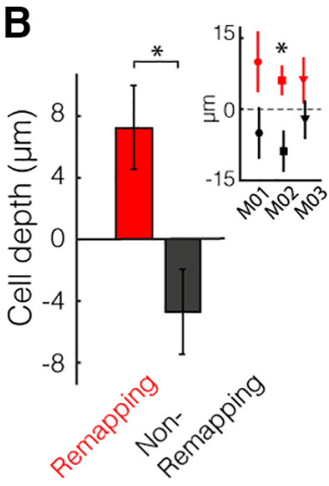

C

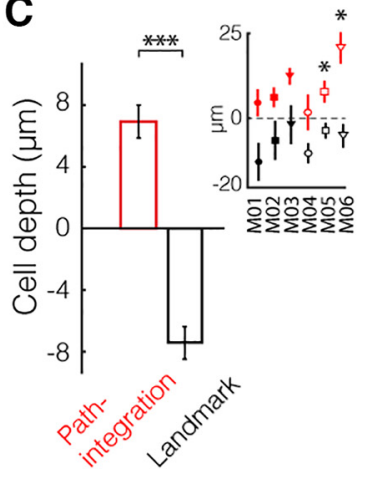

Figure 9. CA1 sublayer localization of non-remapping and remapping cells. $\boldsymbol{A}$, Estimation of the middle of the pyramidal layer. Position of shank and recording sites in the pyramidal layer (left), sharp wave ripple event for unfiltered and $140-230 \mathrm{~Hz}$ bandpass filtered LFP, and ripple power (right) for each recording site. The site with maximum ripple power is used as position $0 . \boldsymbol{B}$, Depth position (mean \pm SEM) for remapping and non-remapping cells and ( $\boldsymbol{C}$ for cells with fields inside (path-integration) and outside (landmark) the cue-impoverished zone. Insets, Cell depths (mean \pm SEM) for individual mice. ${ }^{*} p<0.05,{ }^{* * *} p<0.0001$, two-tailed unpaired $t$ test.

additional mice that received no injections was included in this analysis, $n=40,33$ and 12 cells in each mouse).

\section{Discussion \\ Alteration of path-integration representations by MS inactivation}

We found that muscimol injections in the MS disrupted CA1 spatial representations in the cue-impoverished zone but left representations outside the cue-impoverished zone relatively unaltered, and impaired the ability of mice to estimate the onset of the reward, consistent with a disruption of path-integration function (Martin et al., 2007; Jacob et al., 2017). Controversially, previous studies have reported a diversity of responses to MS inactivation, with MS inactivation affecting or not affecting place field activity in open arenas, and leaving mostly unaltered place field activity on linear tracks while abolishing field activity in a running wheel (Brandon et al., 2011; Koenig et al., 2011; Wang et al., 2015). In light of our findings, the contradictory responses observed in open arenas might reflect the respective absence and presence of cue-impoverished zones in small and large arenas, because of more and less complete spatial coverage by landmark-sensing inputs.

MS inactivation also affected running speed and possibly other behavior aspects such as motivation (although mice still ran and licked for water rewards), which could contribute to changes in cell activity such as the global decrease in firing rate and spatial information we observed. However, it seems unlikely that these behavioral alterations could generate the progressive and consistent shifts of firing fields toward cues. Supporting the spatial nature of behavioral deficits, licking mistakes were progressively confined to the late portion of the cue-impoverished zone, where spatial representation was lacking following the place field shifts. Although the exact mechanism underlying the spatial deficits is unclear, a straightforward explanation is that it originates from the disruption of the grid cell network (Brandon et al., 2011; Koenig et al., 2011), which is hypothesized to support hippocampal spatial representations under path-integration (McNaughton et al., 2006; Solstad et al., 2006; Moser and Moser, 2008).

\section{Differential representations along CA1 radial axis}

A number of studies have outlined differences in molecular expression, anatomical connections (Slomianka et al., 2011; Lee et al., 2014; Kohara et al., 2014; Valero et al., 2015; Masurkar et al., 2017; Li et al., 2017) and place field mechanisms (Mizuseki et al.,
2011; Danielson et al., 2016; Geiller et al., 2017) along the radial axis. While our finding that non-remapping cells encode the cuerich area and populate CA1d is consistent with our previous report (Geiller et al., 2017), our finding that remapping cells populate CA1s and encode the cue-impoverished zone extend current knowledge by revealing a unique ability of CA1s cells to form spatial representations under path-integration.

The difference in CA1d and CA1s place field mechanisms might in part reflect their association with distinct information streams, as suggested by recent anatomical and physiological data. CA1d and CA1s are differentially targeted by cells from the MEC and lateral entorhinal cortex (LEC; Masurkar et al., 2017; Li et al., 2017), with notably calbindin-expressing cells in CA1s receiving most inputs from LEC (Li et al., 2017). Furthermore, CA1d receives most inputs from CA2 (Kohara et al., 2014; Valero et al., 2015) and is possibly more controlled by direct entorhinal cortex inputs (Mizuseki et al., 2011), whereas CA1s is relatively more under the control of CA3 as a result of a twofold stronger afferentation (Kwon et al., 2018) and concerted feedforward inhibition in CA2 and CA1d (Lee et al., 2014; Valero et al., 2015). Accordingly, place fields in both CA3 and CA1s are less affected by changes in reward location (Dupret et al., 2010; Danielson et al., 2016), are more sensitive to MS inactivation (Mizumori et al., 1989; current findings) and encode the treadmill layout in a similar manner (Geiller et al., 2017), and CA1 cells are activated sequentially from CA1d-to-CA1s during ripple oscillations in vitro (Hongo et al., 2015), matching the CA2-to-CA3 sequence reported in vivo (Oliva et al., 2016). The CA3-CA1s stream might be better suited for path-integration for several reasons. Although MEC inputs target both CA3 and CA2 (Andersen, 2007; Chevaleyre and Siegelbaum, 2010; Kohara et al., 2014), CA3CA1s might form a functional loop with MEC grid cells, considering that CA1s generates CA1 feedback projections to the entorhinal cortex (Slomianka et al., 2011) and that these projections are required for grid cell function (Bonnevie et al., 2013). CA3-CA1s might also better integrate grid-cell information because of CA3 recurrent connections (Andersen, 2007). Finally, the CA3 recurrent network might implement some pathintegration operations (Samsonovich and McNaughton, 1997).

\section{Pattern and dynamic of the spatial reconfiguration}

A major effect of MS inactivation on remapping cell activity was a contraction of the spatial representation toward the vicinity of the cues. Hence, the mechanism underlying the existence of cells' 
place field was relatively preserved, but the mechanism implementing the field positions was altered, suggesting a dissociation of the two mechanisms (Miao et al., 2015; Rueckemann et al., 2016). As a result, spatial representation in the late part of the cue-impoverished zone was depleted, which might explain the licking patterns under muscimol: licking mistakes were progressively restricted to the late part of the cue-impoverished zone, suggesting that mice could eventually learn to avoid licking mistakes in the early part but not in the late part, due to the lack of spatial representation.

Furthermore, place field shift was not an immediate and random process but developed over the course of several trials, mainly in the backward direction. In several cells, a gradual backward drift of place fields was visible, reminiscent of the one generated in CA1s by the manipulation of landmarks (Geiller et al., 2017). Considering their time course and lasting effect, it is difficult to explain the backward drifts as anything other than the result of synaptic changes, with the backward direction possibly reflecting the asymmetric nature of spike time-dependent plasticity (Mehta et al., 2000; Dan and Poo, 2004). Hence, activitydependent synaptic plasticity, instead of MS inactivation, was likely the direct cause for the collapse of the spatial representation (accordingly, anticipatory lickings were relatively accurate on the first muscimol trial and became inaccurate in the subsequent trials). However, the fact that the original spatial representation was gradually reinstated during the recovery session argues that a set of synaptic inputs was unchanged and could shift the network back to its initial state. A possible scenario is that grid cells were placed offline during MS inactivation (Brandon et al., 2011; Koenig et al., 2011) and helped restore the original representation following recovery, while CA3-CA1s intrinsic networks could initially support path-integration representations under musci$\mathrm{mol}$ (for path-integration representations in the absence of grid cells, see Bjerknes et al., 2018) and sustained the synaptic changes underlying place field drifts.

\section{Conclusion}

Recent MS inactivation studies (Brandon et al., 2011; Koenig et al., 2011; Wang et al., 2015) have challenged the view that place cells are predominantly generated by path-integration (McNaughton et al., 1996, 2006). Our finding that landmark and path-integration information are differentially represented along the CA1 radial axis further challenges that notion by suggesting parallel implementation of landmark and path-integrationbased spatial representations. Together with CA3, CA1s may be part of a circuit that encodes position on a global context level via integration of self-motion, landmark and memory information, and for which grid cell input is necessary for spreading spatial representations far from landmarks. Such circuit may be critical for global positioning and route planning in familiar environments (Muller et al., 1996). In contrast, CAld cells implement spatial representations on a more specific level, potentially in reference to single landmarks (Geiller et al., 2017), and might be critical for encoding object locations and spatial associations. While a segregation of the two circuits might help prevent interference in computations, their interaction, under control of local inhibition (Lee et al., 2014; Valero et al., 2015), might be critical for binding and recalling together various levels of episodic information.

\section{References}

Andersen P (2007) The hippocampus book. New York: Oxford UP. Bjerknes TL, Dagslott NC, Moser EI, Moser MB (2018) Path integration in place cells of developing rats. Proc Natl Acad Sci U S A 115:E1637-E1646. CrossRef Medline

Bokil H, Andrews P, Kulkarni JE, Mehta S, Mitra PP (2010) Chronux: a platform for analyzing neural signals. J Neurosci Methods 192:146-151. CrossRef Medline

Bonnevie T, Dunn B, Fyhn M, Hafting T, Derdikman D, Kubie JL, Roudi Y, Moser EI, Moser MB (2013) Grid cells require excitatory drive from the hippocampus. Nat Neurosci 16:309-317. CrossRef Medline

Brandon MP, Bogaard AR, Libby CP, Connerney MA, Gupta K, Hasselmo ME (2011) Reduction of theta rhythm dissociates grid cell spatial periodicity from directional tuning. Science 332:595-599. CrossRef Medline

Brandon MP, Koenig J, Leutgeb JK, Leutgeb S (2014) New and distinct hippocampal place codes are generated in a new environment during septal inactivation. Neuron 82:789-796. CrossRef Medline

Brun VH, Leutgeb S, Wu HQ, Schwarcz R, Witter MP, Moser EI, Moser MB (2008) Impaired spatial representation in CA1 after lesion of direct input from entorhinal cortex. Neuron 57:290-302. CrossRef Medline

Burke SN, Maurer AP, Nematollahi S, Uprety AR, Wallace JL, Barnes CA (2011) The influence of objects on place field expression and size in distal hippocampal CA1. Hippocampus 21:783-801. CrossRef Medline

Chen G, Manson D, Cacucci F, Wills TJ (2016) Absence of visual input results in the disruption of grid cell firing in the mouse. Curr Biol 26: 2335-2342. CrossRef Medline

Cheng S, Frank LM (2011) The structure of networks that produce the transformation from grid cells to place cells. Neuroscience 197:293-306. CrossRef Medline

Chevaleyre V, Siegelbaum SA (2010) Strong CA2 pyramidal neuron synapses define a powerful disynaptic cortico-hippocampal loop. Neuron 66:560-572. CrossRef Medline

Chung J, Sharif F, Jung D, Kim S, Royer S (2017) Micro-drive and headgear for chronic implant and recovery of optoelectronic probes. Sci Rep 7:2773. CrossRef Medline

Ciocchi S, Passecker J, Malagon-Vina H, Mikus N, Klausberger T (2015) Brain computation: selective information routing by ventral hippocampal CA1 projection neurons. Science 348:560-563. CrossRef Medline

Dan Y, Poo MM (2004) Spike timing-dependent plasticity of neural circuits. Neuron 44:23-30. CrossRef Medline

Danielson NB, Zaremba JD, Kaifosh P, Bowler J, Ladow M, Losonczy A (2016) Sublayer-specific coding dynamics during spatial navigation and learning in hippocampal area CA1. Neuron 91:652-665. CrossRef Medline

Dupret D, O’Neill J, Pleydell-Bouverie B, Csicsvari J (2010) The reorganization and reactivation of hippocampal maps predict spatial memory performance. Nat Neurosci 13:995-1002. CrossRef Medline

Geiller T, Fattahi M, Choi JS, Roy S (2017) Place cells are more strongly tied to landmarks in deep than in superficial CA1. Nat Commun 8:14531. CrossRef Medline

Hafting T, Fyhn M, Molden S, Moser MB, Moser EI (2005) Microstructure of a spatial map in the entorhinal cortex. Nature 436:801-806. CrossRef Medline

Harris KD, Henze DA, Csicsvari J, Hirase H, Buzsaki G (2000) Accuracy of tetrode spike separation as determined by simultaneous intracellular and extracellular measurements. J Neurophysiol 84:401-414. CrossRef Medline

Hayman RM, Jeffery KJ (2008) How heterogeneous place cell responding arises from homogeneous grids: a contextual gating hypothesis. Hippocampus 18:1301-1313. CrossRef Medline

Hazan L, Zugaro M, Buzsáki G (2006) Klusters, NeuroScope, NDManager: a free software suite for neurophysiological data processing and visualization. J Neurosci Methods 155:207-216. CrossRef Medline

Henriksen EJ, Colgin LL, Barnes CA, Witter MP, Moser MB, Moser EI (2010) Spatial representation along the proximodistal axis of CA1. Neuron 68:127-137. CrossRef Medline

Hongo Y, Ogawa K, Takahara Y, Takasu K, Royer S, Hasegawa M, Sakaguchi G, Ikegaya Y (2015) Topological organization of CA3-to-CA1 excitation. Eur J Neurosci 42:2135-2143. CrossRef Medline

Jacob PY, Gordillo-Salas M, Facchini J, Poucet B, Save E, Sargolini F (2017) Medial entorhinal cortex and medial septum contribute to self-motionbased linear distance estimation. Brain Struct Funct 222:2727-2742. CrossRef Medline

Jung MW, Wiener SI, McNaughton BL (1994) Comparison of spatial firing 
characteristics of units in dorsal and ventral hippocampus of the rat. J Neurosci 14:7347-7356. CrossRef Medline

Kadir SN, Goodman DF, Harris KD (2014) High-dimensional cluster analysis with the masked EM algorithm. Neural Comput 26:2379-2394. CrossRef Medline

Kjelstrup KB, Solstad T, Brun VH, Hafting T, Leutgeb S, Witter MP, Moser EI, Moser MB (2008) Finite scale of spatial representation in the hippocampus. Science 321:140-143. CrossRef Medline

Koenig J, Linder AN, Leutgeb JK, Leutgeb S (2011) The spatial periodicity of grid cells is not sustained during reduced theta oscillations. Science 332: 592-595. CrossRef Medline

Koenig J, Royer S (2013) Learning of reward position associations in a cueenriched treadmill. Soc Neurosci Abstr 191:14.

Kohara K, Pignatelli M, Rivest AJ, Jung HY, Kitamura T, Suh J, Frank D, Kajikawa K, Mise N, Obata Y, Wickersham IR, Tonegawa S (2014) Cell type-specific genetic and optogenetic tools reveal hippocampal CA2 circuits. Nat Neurosci 17:269-279. CrossRef Medline

Krupic J, Bauza M, Burton S, Barry C, O’Keefe J (2015) Grid cell symmetry is shaped by environmental geometry. Nature 518:232-235. CrossRef Medline

Kwon O, Feng L, Druckmann S, Kim J (2018) Schaffer collateral inputs to CA1 excitatory and inhibitory neurons follow different connectivity rules. J Neurosci 38:5140-5152. CrossRef Medline

Lee SH, Marchionni I, Bezaire M, Varga C, Danielson N, Lovett-Barron M, Losonczy A, Soltesz I (2014) Parvalbumin-positive basket cells differentiate among hippocampal pyramidal cells. Neuron 82:1129-1144. CrossRef Medline

Li Y, Xu J, Liu Y, Zhu J, Liu N, Zeng W, Huang N, Rasch MJ, Jiang H, Gu X, Li X, Luo M, Li C, Teng J, Chen J, Zeng S, Lin L, Zhang X (2017) A distinct entorhinal cortex to hippocampal CA1 direct circuit for olfactory associative learning. Nat Neurosci 20:559-570. CrossRef Medline

Martin MM, Horn KL, Kusman KJ, Wallace DG (2007) Medial septum lesions disrupt exploratory trip organization: evidence for septohippocampal involvement in dead reckoning. Physiol Behav 90:412-424. CrossRef Medline

Masurkar AV, Srinivas KV, Brann DH, Warren R, Lowes DC, Siegelbaum SA (2017) Medial and lateral entorhinal cortex differentially excite deep versus superficial CA1 pyramidal neurons. Cell Rep 18:148-160. CrossRef Medline

McNaughton BL, Barnes CA, Gerrard JL, Gothard K, Jung MW, Knierim JJ, Kudrimoti H, Qin Y, Skaggs WE, Suster M, Weaver KL (1996) Deciphering the hippocampal polyglot: the hippocampus as a path integration system. J Exp Biol 199:173-185. Medline

McNaughton BL, Battaglia FP, Jensen O, Moser EI, Moser MB (2006) Path integration and the neural basis of the "cognitive map". Nat Rev Neurosci 7:663-678. CrossRef Medline

Mehta MR, Quirk MC, Wilson MA (2000) Experience-dependent asymmetric shape of hippocampal receptive fields. Neuron 25:707-715. CrossRef Medline

Miao C, Cao Q, Ito HT, Yamahachi H, Witter MP, Moser MB, Moser EI (2015) Hippocampal remapping after partial inactivation of the medial entorhinal cortex. Neuron 88:590-603. CrossRef Medline

Mittelstaedt M, Mittelstaedt H (1980) Homing by path integration in a mammal. Naturwissenschaften 67:566-567. CrossRef

Mizumori SJ, McNaughton BL, Barnes CA, Fox KB (1989) Preserved spatial coding in hippocampal CA1 pyramidal cells during reversible suppression of CA3c output: evidence for pattern completion in hippocampus. J Neurosci 9:3915-3928. CrossRef Medline

Mizuseki K, Diba K, Pastalkova E, Buzsáki G (2011) Hippocampal CA1 pyramidal cells form functionally distinct sublayers. Nat Neurosci 14:11741181. CrossRef Medline

Moser EI, Moser MB (2008) A metric for space. Hippocampus 18:11421156. CrossRef Medline
Muessig L, Hauser J, Wills TJ, Cacucci F (2015) A developmental switch in place cell accuracy coincides with grid cell maturation. Neuron 86:11671173. CrossRef Medline

Muller RU, Stead M, Pach J (1996) The hippocampus as a cognitive graph. J Gen Physiol 107:663-694. CrossRef Medline

O’Keefe J, Dostrovsky J (1971) The hippocampus as a spatial map: preliminary evidence from unit activity in the freely-moving rat. Brain Res 34: 171-175. CrossRef Medline

Oliva A, Fernández-Ruiz A, Buzsáki G, Berényi A (2016) Role of hippocampal CA2 region in triggering sharp-wave ripples. Neuron 91:1342-1355. CrossRef Medline

Royer S, Sirota A, Patel J, Buzsáki G (2010) Distinct representations and theta dynamics in dorsal and ventral hippocampus. J Neurosci 30:17771787. CrossRef Medline

Royer S, Zemelman BV, Losonczy A, Kim J, Chance F, Magee JC, Buzsáki G (2012) Control of timing, rate and bursts of hippocampal place cells by dendritic and somatic inhibition. Nat Neurosci 15:769-775. CrossRef Medline

Rueckemann JW, DiMauro AJ, Rangel LM, Han X, Boyden ES, Eichenbaum $\mathrm{H}$ (2016) Transient optogenetic inactivation of the medial entorhinal cortex biases the active population of hippocampal neurons. Hippocampus 26:246-260. CrossRef Medline

Samsonovich A, McNaughton BL (1997) Path integration and cognitive mapping in a continuous attractor neural network model. J Neurosci 17:5900-5920. CrossRef Medline

Savelli F, Yoganarasimha D, Knierim JJ (2008) Influence of boundary removal on the spatial representations of the medial entorhinal cortex. Hippocampus 18:1270-1282. CrossRef Medline

Schlesiger MI, Cannova CC, Boublil BL, Hales JB, Mankin EA, Brandon MP, Leutgeb JK, Leibold C, Leutgeb S (2015) The medial entorhinal cortex is necessary for temporal organization of hippocampal neuronal activity. Nat Neurosci 18:1123-1132. CrossRef Medline

Schmitzer-Torbert N, Jackson J, Henze D, Harris K, Redish AD (2005) Quantitative measures of cluster quality for use in extracellular recordings. Neuroscience 131:1-11. CrossRef Medline

Skaggs WE, McNaughton BL, Wilson MA, Barnes CA (1996) Theta phase precession in hippocampal neuronal populations and the compression of temporal sequences. Hippocampus 6:149-172. CrossRef Medline

Slomianka L, Amrein I, Knuesel I, Sørensen JC, Wolfer DP (2011) Hippocampal pyramidal cells: the reemergence of cortical lamination. Brain Struct Funct 216:301-317. CrossRef Medline

Solstad T, Moser EI, Einevoll GT (2006) From grid cells to place cells: a mathematical model. Hippocampus 16:1026-1031. CrossRef Medline

Solstad T, Boccara CN, Kropff E, Moser MB, Moser EI (2008) Representation of geometric borders in the entorhinal cortex. Science 322:18651868. CrossRef Medline

Valero M, Cid E, Averkin RG, Aguilar J, Sanchez-Aguilera A, Viney TJ, Gomez-Dominguez D, Bellistri E, de la Prida LM (2015) Determinants of different deep and superficial CA1 pyramidal cell dynamics during sharp-wave ripples. Nat Neurosci 18:1281-1290. CrossRef Medline

Villette V, Malvache A, Tressard T, Dupuy N, Cossart R (2015) Internally recurring hippocampal sequences as a population template of spatiotemporal information. Neuron 88:357-366. CrossRef Medline

Wang Y, Romani S, Lustig B, Leonardo A, Pastalkova E (2015) Theta sequences are essential for internally generated hippocampal firing fields. Nat Neurosci 18:282-288. CrossRef Medline

Winson J (1978) Loss of hippocampal theta rhythm results in spatial memory deficit in the rat. Science 201:160-163. CrossRef Medline

Ylinen A, Bragin A, Nádasdy Z, Jandó G, Szabó I, Sik A, Buzsáki G (1995) Sharp wave-associated high-frequency oscillation $(200 \mathrm{~Hz})$ in the intact hippocampus: network and intracellular mechanisms. J Neurosci 15:30 46. CrossRef Medline 